\title{
Pemodelan dan Simulasi Robot Lengan 3 DOF Menggunakan V-REP
}

\author{
Az Uchrowi, Lasmadi*, Sutjianto \\ Departemen Teknik Elektro, Sekolah Tinggi Teknologi Adisutjipto, Yogyakarta \\ * email: lasmadi.sie14@mail.ugm.ac.id
}

\begin{abstract}
Movement of objects from one position to another position is usually by conventional method of human strength. Development of robotics technology makes movement of objects in the industry by arm robot system. By using arm robot system, the work more effective. The aim of this research is to modeling 3 Degree of Freedom arm robot with kinematics method using $V$-REP software. Kinematics method is a subject that analyze robot movement without knowing the force that causes the movement. This research use the forward kinematics method so that arm robot can reach the goals. The input from this robot is an angle which is computed using the forward kinematics method. The output is an end-effector coordinate. Based on the result of the research, the 3 Degree of Freedom arm robot is capable to move the object from one position to another position and an error that occurs can achieve 4,99\% for x coordinate, $5,57 \%$ for y coordinate, and 3,18\% for $z$ coordinate. Based on these results, the 3 Degree of Freedom arm robot with the forward kinematics method can be simulated in V-REP software effectively.
\end{abstract}

Keywords - Arm robot, Degree of freedom, Forward Kinematics.

\section{Pendahuluan}

Kemajuan teknologi pada akhir-akhir ini semakin meningkatkan kreasi manusia dalam menciptakan peralatan dengan tujuan meningkatkan kualitas hidup. Manusia semakin berupaya membuat perangkat pembantu agar kerja manusia lebih cepat dan ringan. Sebagai contohnya, perancangan dan pembuatan robot yang semakin berkembang seiring tuntutan kebutuhan manusia.

Dalam bidang industri, pemindahan dan penyimpanan barang dari satu posisi ke posisi lain membutuhkan suatu perangkat yang dapat bekerja dengan cepat dan tepat. Namun pada kenyataannya pada saat ini masih banyak industri yang menggunakan tenaga manusia dalam proses pemindahan barang dari satu posisi ke posisi yang lain. Pada dasarnya manusia mampu melakukan pekerjaan pemindahan barang dengan cepat dan tepat, akan tetapi manusia juga mempunyai kekurangan dari segi tenaga maupun konsentrasi kerja. Hal itu tentunya sangat berpengaruh terhadap efektifitas pekerjaan yang dilakukan.

Berdasarkan permasalahan tersebut diperlukan sebuah robot lengan 3 derajat kebebasan yang mampu melakukan tugas memindahkan barang dari satu posisi ke posisi lain. Sehingga diharapkan mampu mempermudah kegiatan pemindahan barang yang dilakukan serta meningkatkan tingkat efektifitas baik dalam hal waktu, tenaga maupun biaya produksi. Robot lengan 3 derajat kebebasan ini akan bertugas melakukan proses perpindahan barang dari satu posisi ke posisi yang lain.

\subsection{Kajian Pustaka}

Penelitian tentang robotika yang menggunakan metode inverse kinematics telah dilakukan oleh Utomo dan Munadi (2013) [10]. Pada penelitian ini pengambilan data dilakukan menggunakan perangkat keras simulator arm robot dan untuk memverifikasi hasil pengambilan data menggunakan perangkat lunak RoboAnalyzer. Dari hasil penelitian diperoleh bahwa terdapat perbedaan antara data pengamatan yang dilakukan dengan menggunakan perangkat 
keras simulator arm robot dengan hasil verifikasi data menggunakan perangkat lunak RoboAnalyzer, hal ini kemungkinan disebabkan olehtidak tepat di tengahhubungan antar link terhadap joint pada proses assembly.

Penelitian oleh Prasetia dan Agustinah (2015) juga menggunakan metode inverse kinematics dengan pendekatan geometri pada robot denso manipulator [5]. Pada penelitian ini pengambilan data dilakukan menggunakan perangkat lunak toolbox Peter Corke versi 8 dan untuk memverifikasi hasil pengambilan data menggunakan analisis inverse kinematics dengan pendekatan geometri. Dari hasil penelitian, solusi inverse kinematics dengan pendekatan geometri akan menghasilkan delapan kondisi pergerakan robot denso manipulator. Delapan kondisi itu menunjukan pergerakan robot untuk mencapai titik tujuan robot yang diinginkan.

Kemudian, penelitian oleh Benu (2016) yang berjudul "Rancang Bangun Sistem Kendali Lengan Robot 3 Sendi Berbasis Programmable Logic Controller (PLC)" [2]. Penelitian tersebut membahas tentang bagaimana sebuah robot lengan 3 sendi dapat memindah suatu barang dari satu posisi ke posisi yang lain. Kekurangan dari penelitian ini yaitu masih menggunakan PLC dalam pengoperasian robot, sehingga robot tersebut dinilai masih kurang efektif. Selain itu pada penelitian tersebut juga tidak dibahas mengenai ketepatan robot dalam meletakkan suatu benda pada saat proses pemidahan.

\subsection{Landasan Teori}

Adapun beberapa dasar teori untuk mendukung penelitian ini adalah sebagai berikut.

\section{A. Definisi Robot Lengan}

Menurut RIA (Robot Institute of America), robot lengan atau robot manipulatoradalah robot multifungsi yang didesain untuk memindahkan material, peralatan atau sebuah piranti. Robot ini mempunyai derajat kebebasan atau Degree of Freedom (DOF) gerak yang linier pada sebuah sumbu (axis) [8].Robot ini hanya memiliki satu tangan seperti tangan manusia yang fungsinya untuk memegang atau memindahkan barang. Robot manipulator merupakan sebuah rangkaian benda kaku (rigid bodies) terbuka yang terdiri atas sendi dan terhubung dengan link dimana setiap posisi sendi ditentukan dengan variabel tunggal sehingga jumlah sendi sama dengan nilai derajat kebebasan [10]. Robot manipulator ditunjukkan pada Gambar 1.

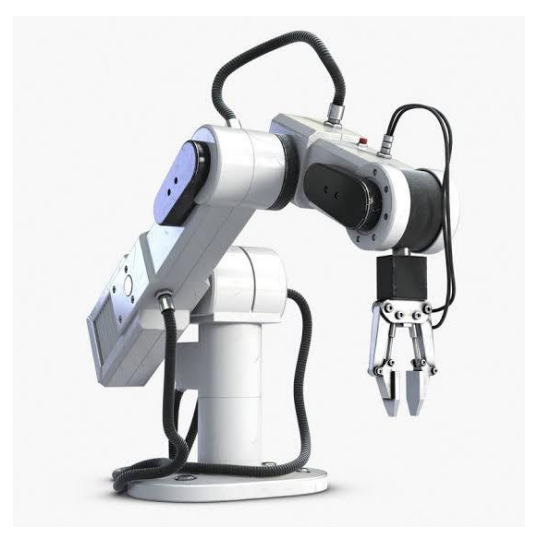

Gambar 1. Robot Lengan

\section{B. Link dan Joint}

Link merupakan bagian-bagian kerangka kaku yang dihubungkan secara bersamaan sehingga membentuk suatu rangkaian robot. Sedangkan joint (sendi) yaitu koneksi antar link yang dapat menentukan pergerakan. Gambar 2 menunjukkan bagian link dan joint pada suatu robot lengan. 


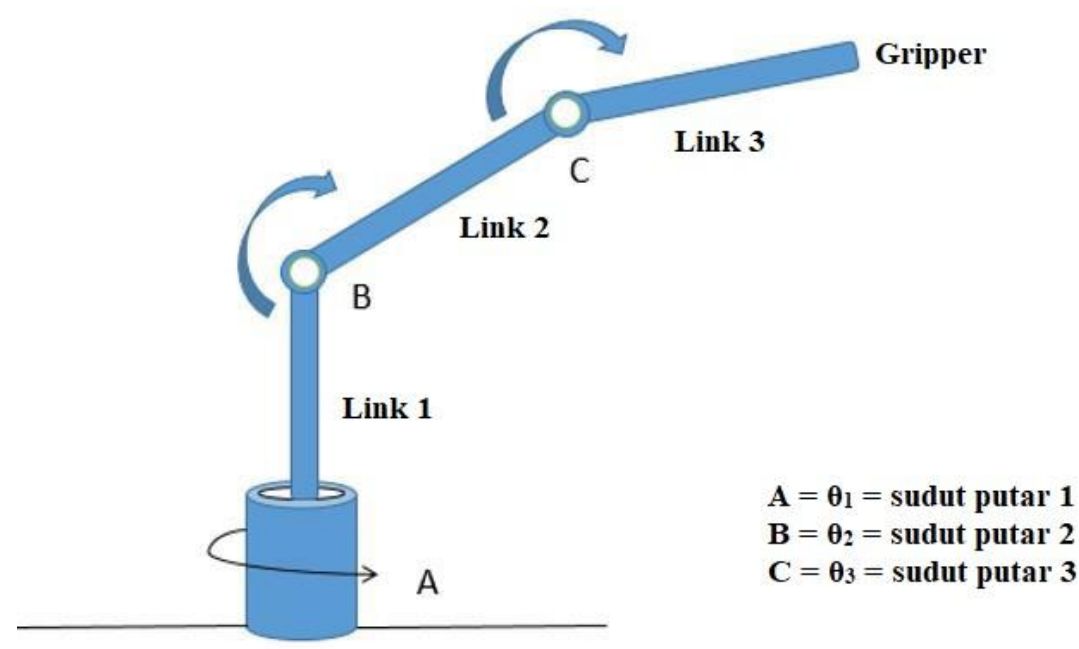

Gambar 2. Ilustrasi Link dan Joint

C. Derajat Kebebasan Gerak

Derajat kebebasan gerak atau Degree of Freedom (DOF) dari sebuah sistem robotik dapat dibandingkan dengan bagaimana tubuh manusia bergerak. Sama halnya dengan manusia, untuk setiap derajat kebebasan gerak pada robot, dibutuhkan sebuah sendi. Secara umum total derajat kebebasan gerak yang dibutuhkan untuk menggerakkan sebuah lengan robot adalah enam buah. Meski enam derajat kebebasan gerak dibutuhkan untuk mencapai fleksibilitas maksimum, namun kebanyakan robot hanya menggunakan 3 sampai 5 derajat kebebasan gerak.

Semakin banyak derajat kebebasan gerak, semakin kompleks pergerakan yang dapat dilakukan dan semakin kompleks juga pemrograman serta perhitungannya. Terdapat tiga buah derajat kebebasan gerak yang terletak pada lengan, antara lain yaitu rotational reverse, radial transverse, dan vertical transverse. Terdapat pula tiga buah derajat kebebasan gerak yang terletak pada pergelangan tangan, antara lain yaitu pitch, roll, dan yaw [7]. Adapun gambar mengenai enam derajat kebebasan gerak utama pada robot dapat dilihat pada Gambar 3.

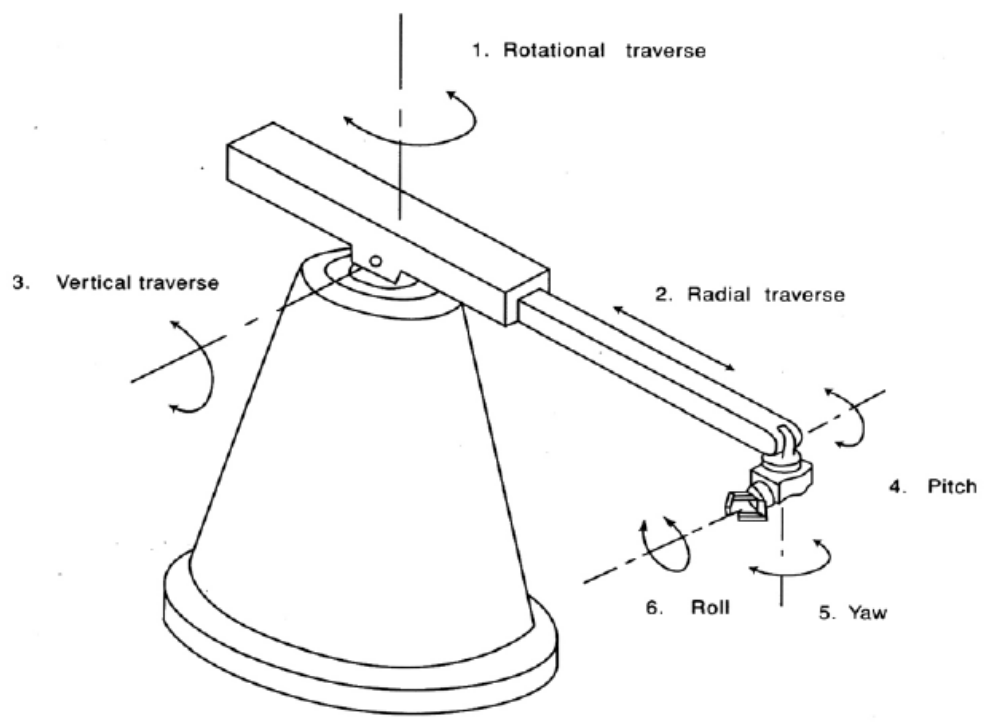

Gambar 3. Enam Derajat Kebebasan Gerak Utama pada Robot 


\section{Kinematika Robot}

Kinematika robot adalah studi analisis pergerakan kaki atau lengan robot terhadap sistem kerangka koordinat acuan yang diam/bergerak tanpa memperhatikan gaya yang menyebabkan pergerakan tersebut. Model kinematika merepresentasikan hubungan end effector dalam ruang tiga dimensi dengan variabel sendi dalam ruang sendi. Persamaan kinematika maju (forward kinematics) mendeskripsikan posisi dan orientasi end effector yang dinyatakan dalam posisi sendi. Sedangkan persamaan kinematika balik (inverse kinematics) mendeskripsikan konfigurasi posisi sendi untuk menghasilkan posisi dan orientasi end effector tertentu [1].Gambar 4 menunjukan diagram blok sederhana dari konsep kinematika robot.

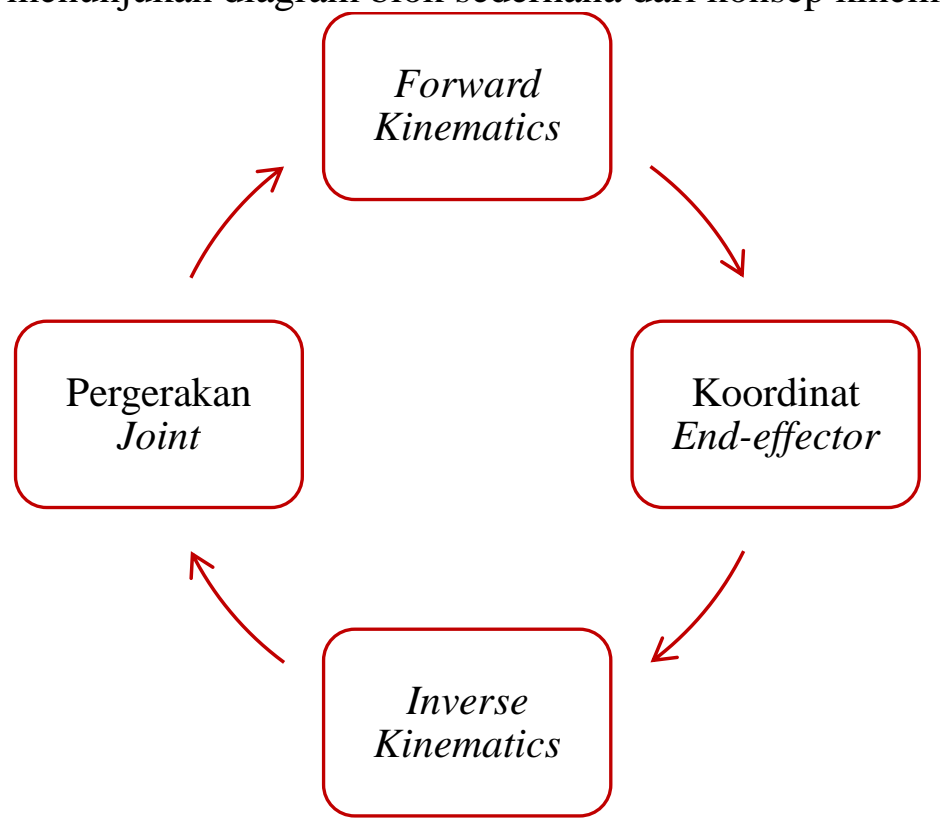

Gambar 4. Diagram Blok Kinematika

\section{E. Forward Kinematics}

Kinematika maju atau forward kinematics merupakan suatu proses menghitung posisi dari end-effector berdasarkan sudut-sudut joint yang diketahui dengan keluaran berupa koordinat end-effector. Terdapat dua metode untuk menyelesaikan perhitungan forward kinematics, antara lain yaitu metode Denavit-Hartenberg (D-H) dan metode geometri.

\section{1) Metode Denavit-Hartenberg (D-H)}

Prinsip dasar representasi D-H adalah suatu matriks $(4 \mathrm{x} 4)$ yang berupa sistem koordinat dari suatu link dengan link yang terhubung pada pangkalnya (link sebelumnya). Dalam konfigurasi serial, koordinat (ujung) link-1 dihitung berdasarkan joint-1 atau sendi pada tubuh robot. Koordinat pada link-2 dihitung berdasarkan joint-2 yang berada di ujung link-1 dengan mengasumsikan link-1 adalah basis gerakan link-2. Demikian seterusnya, link-3 dihitung berdasarkan link-2, hingga link ke-n dihitung berdasarkan link ke-(n-1) [3]. Untuk link dengan konfigurasi joint putaran, matriks A pada joint ke-n dapat dilihat pada persamaan (1).

$$
A_{n}=\left[\begin{array}{cccc}
\cos \theta_{n} & -\sin \theta_{n} \cos \alpha_{n} & \sin \theta_{n} \sin \alpha_{n} & k_{n} \cos \theta_{n} \\
\sin \theta_{n} & \cos \theta_{n} \cos \alpha_{n} & -\cos \theta_{n} \sin \alpha_{n} & k_{n} \sin \theta_{n} \\
0 & \sin \alpha_{n} & \cos \alpha_{n} & d_{n} \\
0 & 0 & 0 & 1
\end{array}\right]
$$




\section{2) Metode Geometri}

Dalam metode geometri jumlah joint (sendi) pada robot akan sangat berpengaruh terhadap persamaan yang akan digunakan untuk mencari koordinat posisi robot atau benda. Semakin banyak jumlah joint pada robot maka akan semakin kompleks juga persamaannya. Penjelasan joint dan link pada robot lengan 3 derajat kebebasan ditunjukkan pada Gambar 5.
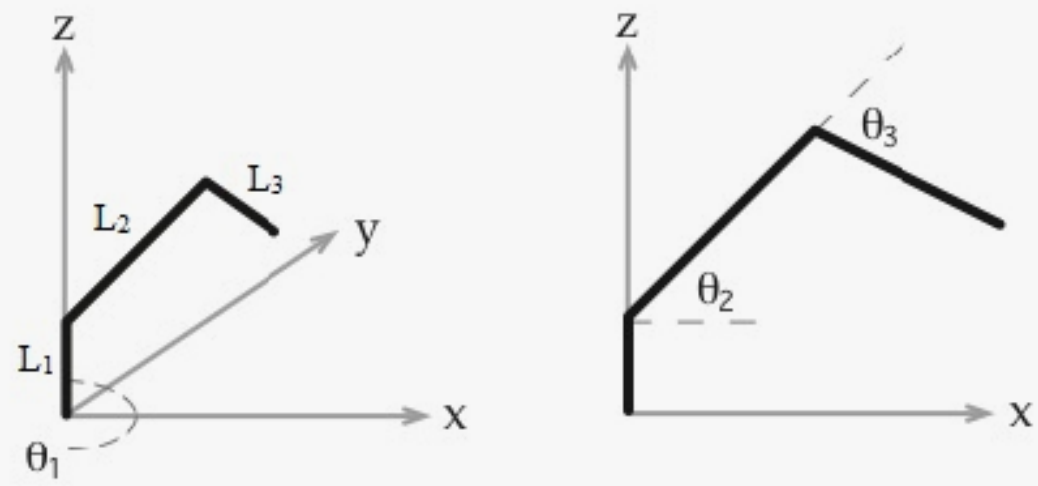

Gambar 5. Ilustrasi Joint dan Link Robot Lengan 3 Derajat Kebebasan

Gambar 5 menggambarkan representasi robot lengan 3 derajat kebebasan dalam keadaan ideal, dimana tidak terdapat sambungan-sambungan khusus antar link dan juga tidak adanya sambungan pada ujung end-effector [6]. Untuk mencari koordinat posisi robot atau benda dapat dilihat pada persamaan (2), persamaan (3), dan persamaan (4).

$$
\begin{aligned}
& x=\left\{\left(L_{2} \cos \theta_{2}\right)+\left(L_{3} \cos \left(\theta_{3}-\theta_{2}\right)\right)\right\} \times \cos \theta_{1} \\
& y=\left\{\left(L_{2} \cos \theta_{2}\right)+\left(L_{3} \cos \left(\theta_{3}-\theta_{2}\right)\right)\right\} \times \sin \theta_{1} \\
& z=L_{1}+\left(L_{2} \sin \theta_{2}\right)-\left(L_{3} \sin \left(\theta_{3}-\theta_{2}\right)\right)
\end{aligned}
$$

Dengan,

$$
\begin{array}{lll}
\mathrm{x}=\text { koordinat } \mathrm{x} \text { (absis) } & \mathrm{L}_{1}=\text { panjang link } 1 & \theta_{1}=\text { sudut motor } 1 \\
\mathrm{y}=\text { koordinat } \mathrm{y} \text { (ordinat) } & \mathrm{L}_{2}=\text { panjang link } 2 & \theta_{2}=\text { sudut motor } 2 \\
\mathrm{z}=\text { koordinat } \mathrm{z} \text { (aplikat) } & \mathrm{L}_{3}=\text { panjang link } 3 & \theta_{3}=\text { sudut motor } 3 .
\end{array}
$$

\section{F. Standar Deviasi dan Persentase Kesalahan}

Standar deviasi merupakan ukuran variansi yang paling banyak digunakan, karena nilainya paling memenuhi kriteria statistika. Standar deviasi adalah akar kuadrat dari variansi. Variansi dicari dengan menghitung selisih dari setiap elemen data dengan rata-rata. Rata-rata merupakan jumlah elemen data dibagi dengan jumlah data [11]. Rumus untuk mencari variansi dan standar deviasi ditunjukkan pada persamaan (5).

$$
\sigma_{n}=\sqrt{\frac{\sum_{i=1}^{N}\left(n_{i}-\bar{n}\right)^{2}}{N}}
$$

Dimana,

$$
\begin{array}{ll}
\sigma=\text { standar deviasi } & n_{i}=\text { elemen data } \mathrm{n} \text { ke- } \mathrm{i} \\
n=\text { koordinat }(\mathrm{x}, \mathrm{y}, \mathrm{z}) & i=1,2,3, \ldots, \mathrm{N} \\
\bar{n}=\text { rata-rata koordinat }(\mathrm{x}, \mathrm{y}, \mathrm{z}) & \mathrm{N}=\text { jumlah data }
\end{array}
$$




\section{Rancangan Sistem}

Adapun diagram blok perancangan sistem dapat dilihat pada Gambar 6.

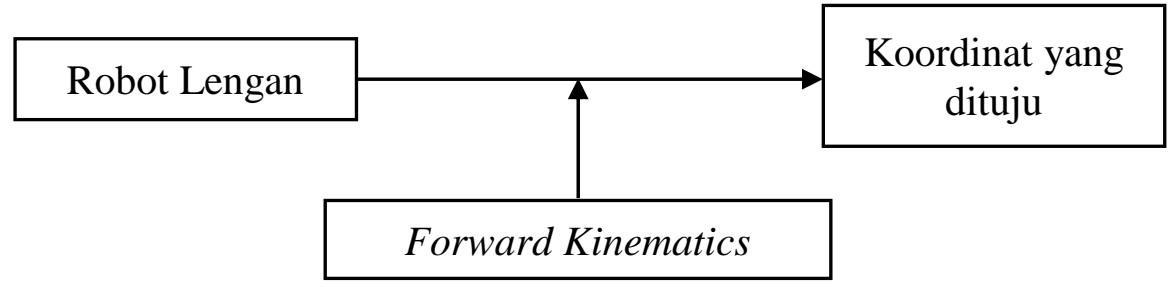

Gambar 6. Diagram Blok Perancangan Sistem

\section{Hasil Penelitian}

Pada bagian ini akan dibahas mengenai hasil pemodelan sistem, hasil simulasi pengujian gerak robot lengan, pembahasan hasil pengujian gerak robot lengan, dan hasil pengujian repeatability pada V-REP.

\subsection{Hasil Pemodelan Sistem}

V-REP (Virtual Robot Experimentation Platform) merupakan perangkatlunak komputer yang digunakan untuk membuat simulasi robot dalamwujud 3D atau 3 dimensi [4]. Gambar 7 menunjukkan hasil pemodelan sistem pada penelitian ini.

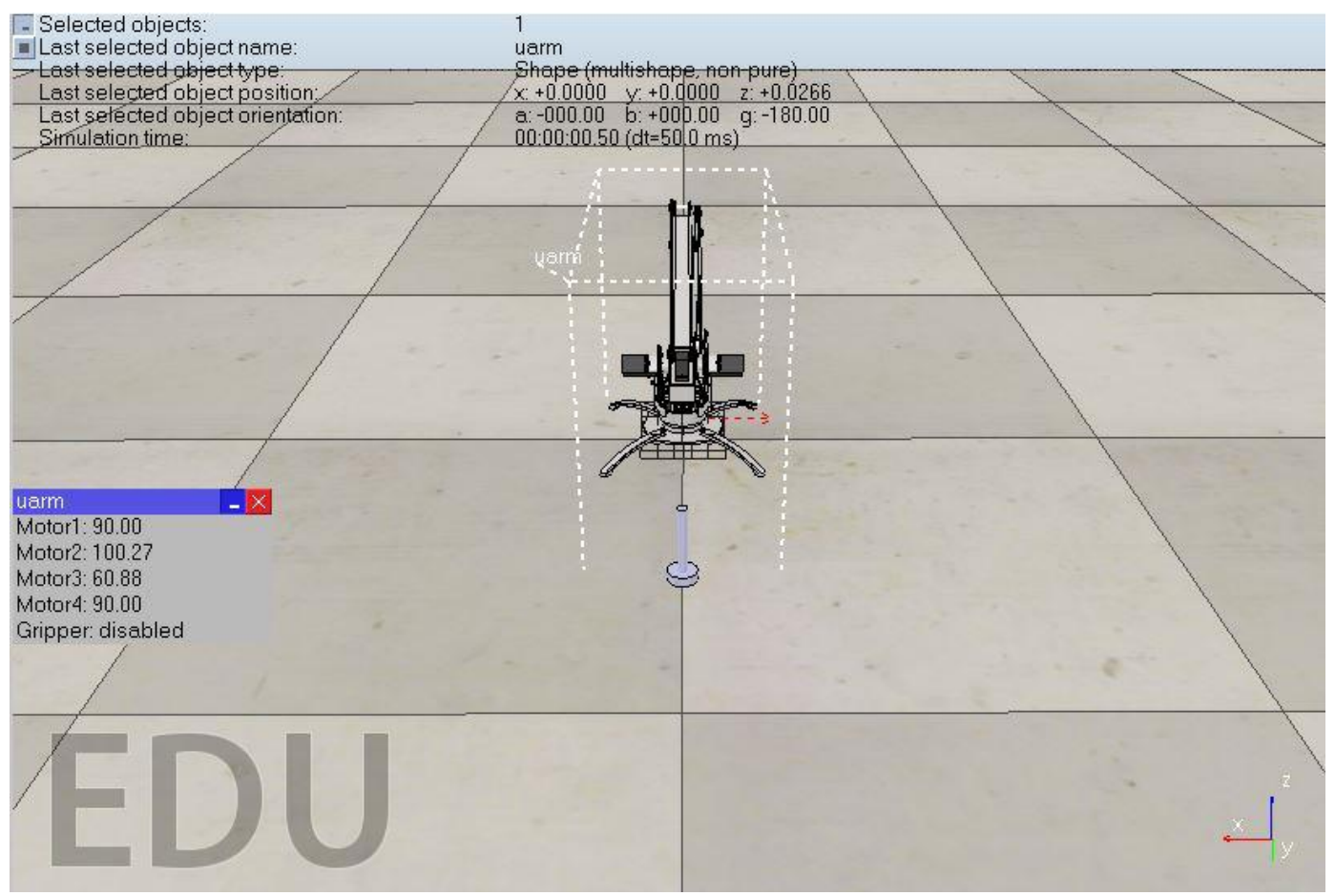

Gambar 7. Hasil Pemodelan Sistem

\subsection{Hasil Simulasi Pengujian Gerak Robot Lengan}

Simulasi gerak robot lengan dilakukan sebanyak enam kali pengujian, dimana robot akan bertugas untuk meindahkan benda dari satu posisi ke posisi lain. Adapun hasil pengujian gerak robot lengan adalah sebagai berikut. 
A. Hasil simulasi pengujian ke-1

Pada pengujian ke-1 posisi awal benda diletakkan pada koordinat $\mathrm{x}=-9,25 \mathrm{~cm}, \mathrm{y}=$ $30,50 \mathrm{~cm}$, dan $\mathrm{z}=4,00 \mathrm{~cm}$. Kemudian benda dipindahkan dengan masukan sudut motor sebesar $\theta_{1}=30^{\circ}, \theta_{2}=40,92^{\circ}$, dan $\theta_{3}=79,82^{\circ}$. Setelah benda dipindahkan, koordinat posisi benda terletak pada $\mathrm{x}=30,75 \mathrm{~cm}, \mathrm{y}=17,93 \mathrm{~cm}$, dan $\mathrm{z}=4,00 \mathrm{~cm}$. Adapun grafik perpindahan posisi benda terhadap waktu dapat dilihat pada Gambar 8.

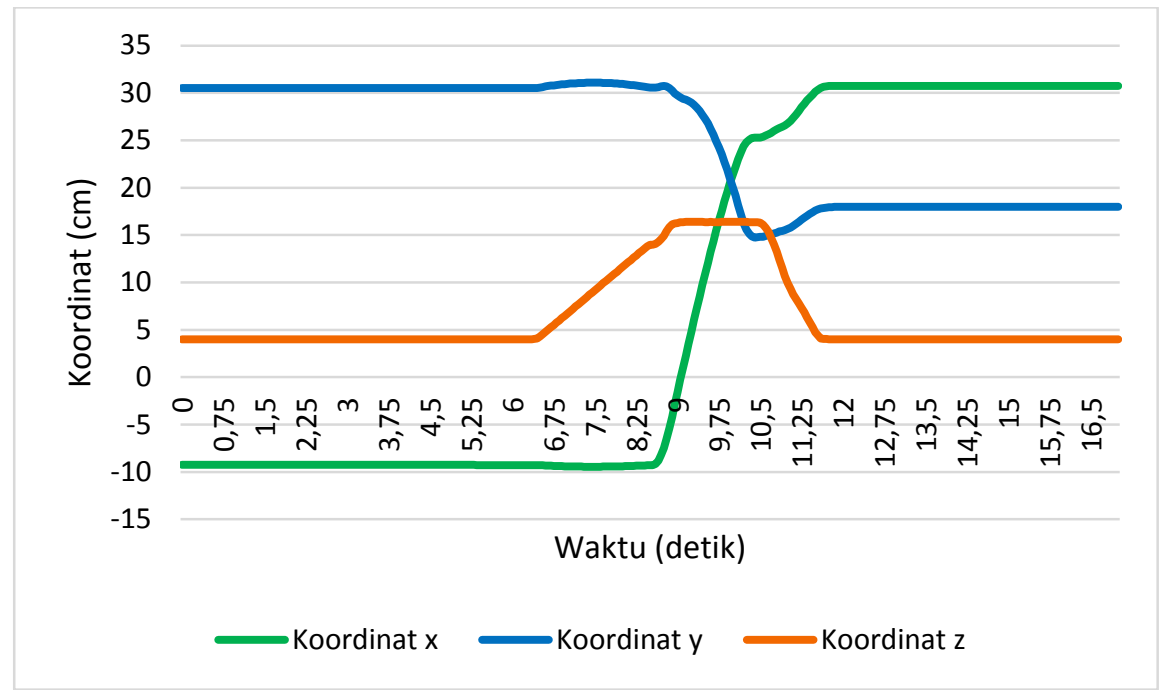

Gambar 8. Grafik Pengujian ke-1

Adapun hasil simulasi pengujian gerak robot lengan pada yang lain dapat dilihat pada Tabel 1.

Tabel 1. Hasil Simulasi Pengujian Gerak Robot Lengan

\begin{tabular}{|c|c|c|c|c|c|c|c|c|c|}
\hline \multirow[t]{2}{*}{$\mathrm{Uji}$} & \multicolumn{3}{|c|}{$\begin{array}{l}\text { Koordinat Awal Benda } \\
\qquad(\mathrm{cm})\end{array}$} & \multicolumn{3}{|c|}{ Sudut Putar Motor } & \multicolumn{3}{|c|}{$\begin{array}{l}\text { Koordinat Akhir Benda } \\
\qquad(\mathrm{cm})\end{array}$} \\
\hline & $\mathrm{x}$ & $\mathrm{y}$ & $\mathrm{Z}$ & $\theta_{1}$ & $\theta_{2}$ & $\theta_{3}$ & $\mathrm{X}$ & $\mathrm{y}$ & $\mathrm{Z}$ \\
\hline 1 & $-9,25$ & 30,50 & 4,00 & $30^{\circ}$ & $40,92^{\circ}$ & $79,82^{\circ}$ & 30,75 & 17,93 & 4,00 \\
\hline 2 & $-21,75$ & 23,00 & 4,00 & $60^{\circ}$ & $41,68^{\circ}$ & $80,69^{\circ}$ & 17,61 & 30,72 & 4,00 \\
\hline 3 & $-35,00$ & 11,50 & 4,00 & $90^{\circ}$ & $41,98^{\circ}$ & $81,03^{\circ}$ & 0,02 & 35,32 & 4,00 \\
\hline 4 & 0,00 & 15,35 & 4,00 & $120^{\circ}$ & $42,42^{\circ}$ & $81,54^{\circ}$ & $-17,50$ & 30,47 & 4,00 \\
\hline 5 & 33,25 & 9,50 & 4,00 & $150^{\circ}$ & $43,15^{\circ}$ & $82,39^{\circ}$ & $-30,09$ & 17,52 & 4,00 \\
\hline 6 & 40,60 & 0,00 & 4,00 & $180^{\circ}$ & $43,85^{\circ}$ & $83,22^{\circ}$ & $-34,49$ & 0,01 & 4,00 \\
\hline
\end{tabular}

\subsection{Pembahasan Hasil Pengujian Gerak Robot Lengan}

Pada bagian ini akan dibahas mengenai perhitungan koordinat posisi benda setelah dipindahkan berdasarkan teori. Setelah didapatkan hasil perhitungan berdasarkan teori maka dapat diketahui persentase kesalahan dari setiap pengujian simulasi robot. Adapun spesifikasi robot yang digunakan pada penelitian ini ditunjukkan pada Gambar 9 [9]. 


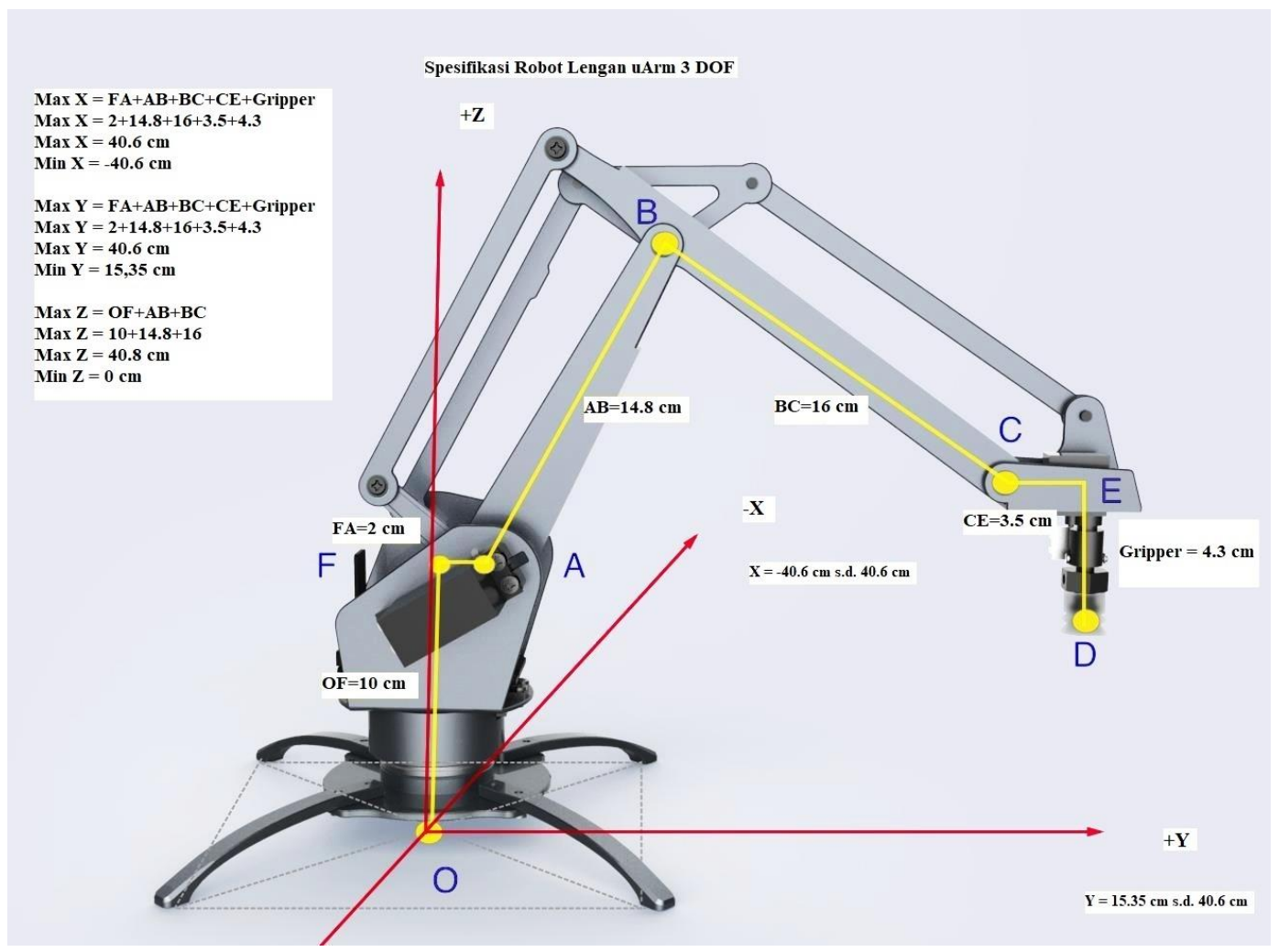

Gambar 9. Spesifikasi Robot Lengan

Dimana,
$\mathrm{OF}=\mathrm{L}_{1}=10 \mathrm{~cm}$
$\mathrm{FA}=2 \mathrm{~cm}$
$\mathrm{AB}=\mathrm{L}_{2}=14,8 \mathrm{~cm}$
$\mathrm{CE}=3,5 \mathrm{~cm}$
$\mathrm{BC}=\mathrm{L}_{3}=16 \mathrm{~cm}$
Gripper $=4,3 \mathrm{~cm}$
$\mathrm{CE}+$ Gripper $=7,8 \mathrm{~cm}$.

Berdasarkan persamaan (2), persamaan (3), dan persamaan (4), koordinat posisi benda dapat dihitung berdasarkan perhitungan teori. Akan tetapi karena kerangka robot yang digunakan pada penelitian ini dinilai kurang ideal karena terdapat sambungan antara link 1 dengan link 2 (FA) sebesar $2 \mathrm{~cm}$, dan terdapat sambungan pada ujung link 3 (CE dan gripper) dengan panjang masing-masing $3,5 \mathrm{~cm}$ dan $4,3 \mathrm{~cm}$ maka persamaan untuk mencari nilai koordinat posisi robot menjadi:

$$
\begin{aligned}
& x=\left\{\left[2+\left(L_{2} \times \cos \theta_{2}\right)\right]+\left[7,8+\left(L_{3} \times \cos \left(\theta_{3}-\theta_{2}\right)\right)\right]\right\} \times \cos \theta_{1} \\
& y=\left\{\left[2+\left(L_{2} \times \cos \theta_{2}\right)\right]+\left[7,8+\left(L_{3} \times \cos \left(\theta_{3}-\theta_{2}\right)\right)\right]\right\} \times \sin \theta_{1} \\
& z=L_{1}+\left[2+\left(L_{2} \times \sin \theta_{2}\right)\right]-\left[7,8+\left(L_{3} \times \sin \left(\theta_{3}-\theta_{2}\right)\right)\right]
\end{aligned}
$$

Dengan,

$\mathrm{x}=$ koordinat $\mathrm{x}$ (absis)

$\mathrm{L}_{1}=$ panjang link 1

$\theta_{1}=$ sudut motor 1

$\mathrm{y}=$ koordinat $\mathrm{y}$ (ordinat)

$\mathrm{L}_{2}=$ panjang link 2

$\theta_{2}=$ sudut motor 2

$\mathrm{z}=$ koordinat $\mathrm{z}$ (aplikat)

$\mathrm{L}_{3}=$ panjang link 3

$\theta_{3}=$ sudut motor 3 . 
Berdasarkan persamaan (6), persamaan (7), dan persamaan (8) dapat diketahui koordinat akhir benda berdasarkan perhitungan teori. Kemudian dari hasil yang didapat berdasarkan simulasi pada V-REP dan hasil pada Tabel 2

Tabel 2. Hasil Perhitungan Pengujian Gerak Robot Lengan

\begin{tabular}{|c|c|c|c|c|c|c|c|c|c|}
\hline \multirow[t]{2}{*}{ Uji } & \multicolumn{3}{|c|}{$\begin{array}{l}\text { Koordinat Akhir Benda } \\
\text { Berdasarkan Simulasi } \\
(\mathrm{cm})\end{array}$} & \multicolumn{3}{|c|}{$\begin{array}{c}\text { Koordinat Akhir Benda } \\
\text { Berdasarkan } \\
\text { Perhitungan }(\mathrm{cm})\end{array}$} & \multicolumn{3}{|c|}{$\begin{array}{c}\text { Persentase Kesalahan } \\
(\%)\end{array}$} \\
\hline & $\mathrm{X}$ & $\mathrm{y}$ & $\mathrm{Z}$ & $\mathrm{X}$ & $\mathrm{y}$ & $\mathrm{Z}$ & $\mathrm{x}$ & $\mathrm{y}$ & $\mathrm{Z}$ \\
\hline 1 & 30,75 & 17,93 & 4,00 & 28,96 & 16,72 & 3,85 & 6,18 & 7,24 & 3,90 \\
\hline 2 & 17,61 & 30,72 & 4,00 & 16,64 & 28,83 & 3,97 & 5,83 & 6,56 & 0,76 \\
\hline 3 & 0,02 & 35,32 & 4,00 & 0,00 & 33,23 & 4,02 & 2,00 & 6,29 & 0,50 \\
\hline 4 & $-17,50$ & 30,47 & 4,00 & $-16,57$ & 28,70 & 4,09 & 5,61 & 6,17 & 2,20 \\
\hline 5 & $-30,09$ & 17,52 & 4,00 & $-28,57$ & 16,50 & 4,20 & 5,32 & 6,18 & 4,76 \\
\hline 6 & $-34,49$ & 0,01 & 4,00 & $-32,84$ & 0,00 & 4,30 & 5,02 & 1,00 & 6,98 \\
\hline \multicolumn{7}{|c|}{ Rata-rata } & 4,99 & 5,57 & 3,18 \\
\hline
\end{tabular}

\subsection{Hasil Pengujian Repeatability pada V-REP}

Repeatability merupakan ukuran seberapa bagus keluaran berulang ke nilai sebelumnya ketika masukan yang sama dengan presisi yang sama diberikan pada waktu-waktu yang berbeda. Repeatability dapat dinyatakan dalam bentuk standar deviasi, dimana semakin kecil nilai standar deviasi maka repeatability semakin baik. Adapun hasil pengujian repeatability pada V-REP adalah sebagai berikut.Pada pengujian ini posisi awal benda diletakkan pada koordinat $\mathrm{x}=-9,25 \mathrm{~cm}, \mathrm{y}=30,50 \mathrm{~cm}$, dan $\mathrm{z}=4,00 \mathrm{~cm}$. Kemudian benda dipindahkan dengan masukan sudut motor sebesar $\theta_{1}=30^{\circ}, \theta_{2}=40,92^{\circ}$, dan $\theta_{3}=79,82^{\circ}$. Koordinat benda sebelum dan setelah dipindahkan ditunjukkan pada Tabel 3 .

Tabel 3. Hasil Pengujian Repeatability

\begin{tabular}{c|c|c|c|c|c|c}
\hline \multirow{2}{*}{ Percobaan } & \multicolumn{3}{|c|}{ Koordinat Awal $(\mathrm{cm})$} & \multicolumn{3}{c}{ Koordinat Akhir(cm) } \\
\cline { 2 - 7 } & $\mathrm{X}$ & $\mathrm{y}$ & $\mathrm{Z}$ & $\mathrm{x}$ & $\mathrm{y}$ & $\mathrm{Z}$ \\
\hline 1 & $-9,25$ & 30,50 & 4,00 & 30,75 & 17,94 & 4,00 \\
\hline 2 & $-9,25$ & 30,50 & 4,00 & 30,74 & 17,94 & 4,00 \\
\hline 3 & $-9,25$ & 30,50 & 4,00 & 30,75 & 17,94 & 4,00 \\
\hline 4 & $-9,25$ & 30,50 & 4,00 & 30,75 & 17,93 & 4,00 \\
\hline 5 & $-9,25$ & 30,50 & 4,00 & 30,73 & 17,93 & 4,00 \\
\hline 6 & $-9,25$ & 30,50 & 4,00 & 30,75 & 17,92 & 4,00 \\
\hline 7 & $-9,25$ & 30,50 & 4,00 & 30,74 & 17,96 & 4,00 \\
\hline 8 & $-9,25$ & 30,50 & 4,00 & 30,75 & 17,93 & 4,00 \\
\hline 9 & $-9,25$ & 30,50 & 4,00 & 30,75 & 17,93 & 4,00 \\
\hline 10 & $-9,25$ & 30,50 & 4,00 & 30,75 & 17,94 & 4,00 \\
\hline \multicolumn{3}{|c|}{ Rata-rata } & 30,75 & 17,94 & 4,00 \\
\hline
\end{tabular}

Berdasarkan nilai rata-rata yang diperoleh dari sepuluh kali percobaan, maka dapat dihitung standar deviasi untuk masing-masing koordinat. Adapun perhitungan standar deviasi untuk masing-masing koordinat adalah sebagai berikut. 
A. Koordinat $\mathrm{x}$

$$
\begin{aligned}
\sigma_{x} & =\sqrt{\frac{\sum_{i=1}^{N}\left(x_{i}-\bar{x}\right)^{2}}{N}} \\
\sigma_{x} & =\sqrt{\frac{(30,75-30,75)^{2}+(30,74-30,75)^{2}+\cdots+(30,75-30,75)^{2}}{10}} \\
\sigma_{x} & =0,01 .
\end{aligned}
$$

B. Koordinat y

$$
\begin{aligned}
& \sigma_{y}=\sqrt{\frac{\sum_{i=1}^{N}\left(y_{i}-\bar{y}\right)^{2}}{N}} \\
& \sigma_{y}=\sqrt{\frac{(17,94-17,94)^{2}+(17,94-17,94)^{2}+\cdots+(17,94-17,94)^{2}}{10}} \\
& \sigma_{y}=0,01 .
\end{aligned}
$$

C. Koordinat $\mathrm{z}$

$$
\begin{aligned}
& \sigma_{z}=\sqrt{\frac{\sum_{i=1}^{N}\left(z_{i}-\bar{z}\right)^{2}}{N}} \\
& \sigma_{z}=\sqrt{\frac{(4,00-4,00)^{2}+(4,00-4,00)^{2}+\cdots+(4,00-4,00)^{2}}{10}} \\
& \sigma_{z}=0,00 .
\end{aligned}
$$

Berdasarkan perhitungan diperoleh hasil standar deviasi 0,01 untuk koordinat $\mathrm{x}$, 0,01 untuk koordinat $\mathrm{y}$, dan 0,00 untuk koordinat z. Nilai standar deviasi tersebut menunjukkan bahwa simulasi robot pada pengujian tersebut repeatability yang baik. Hal tersebut sesuai dengan teori yang ada, dimana semakin kecil nilai standar deviasi maka repeatability semakin baik. Begitu juga sebaliknya, semakin besar nilai standar deviasi maka repeatability semakin buruk.

\section{Kesimpulan}

Kesimpulan yang didapat dari hasil penelitian ini adalah:

1. Metode forward kinematics dapat diterapkan pada simulasi robot lengan 3 derajat kebebasan menggunakan perangkat lunak V-REP.

2. Persentase kesalahan yang terjadi pada penelitian ini sebesar $4,99 \%$ untuk koordinat $\mathrm{x}$, $5,57 \%$ untuk koordinat y, dan 3,18\% untuk koordinat $\mathrm{z}$.

3. Berdasarkan hasil tersebut, robot lengan 3 derajat kebebasan dengan metode forward kinematics dapat disimulasikan pada perangkat lunak V-REP dengan cukup efektif.

4. Standar deviasi yang diperoleh dari pengujian repeatability menunjukkan bahwa simulasi robot lengan 3 derajat kebebasan pada perangkat lunak V-REP repeatability yang baik. 


\section{Daftar Pustaka}

[1] Anggoro, B. (2013). Sejarah dan Perkembangan Robot. Diakses dari Universitas Diponegoro, http://eprints.undip.ac.id/

[2] Benu, D. (2016). Rancang Bangun Sistem Kendali Lengan Robot 3 Sendi Berbasis Programmable Logic Control (PLC). Tugas Akhir Teknik Elektro, STT Adisutjipto, Yogyakarta.

[3] Budiharto, W. (2014). Robotika Modern - Teori dan Implementasi (edisi revisi). Andi.

[4] Jatmiko, W., dkk. (2012). Robotika Teori dan Aplikasi. Depok: Universitas Indonesia. Fakultas Ilmu Komputer Universitas Indonesia.

[5] Prasetia, I. E., \& Agustinah, T. (2015). Invers Kinematics dengan Solusi Closed Form pada Robot Denso Manipulator. Jurnal Teknik ITS, 4(1), 2337-3539.

[6] Rus, D. (2011). Robotic Systems and Science - Forward and Inverse Kinematics. Diakses dari Massachusetts Institute of Technology, http://courses.csail.mit.edu/6.141/

[7] Siswaja, H. D. (2008). Prinsip Kerja dan Klasifikasi Robot. Media Informatika, 7(3).

[8] Sulistyowati, R., \& Kurniawan, M. Y. (2012). Kontrol Posisi pada Lengan Robot Pemindah Barang Berbasis Mikrokontroller ATMega16. In Proseding Seminar Nasional Sains dan Teknologi Terapan Institut Teknologi Adhi Tama Surabaya.

[9] Technology, Ufactory. (2017). uArm Metal Developer Guide. Diakses 26 Desember 2018, dari https://www.ufactory.cc

[10] Utomo, B., \& Munadi. (2013). Analisis Forward dan Invers Kinematics pada Simulator Arm Robot 5 Derajat Kebebasan. Jurnal Teknik Mesin (S-1), 1(3), 11-20.

[11] Wibowo, A. (2012). Nilai Ringkasan Data. Diakses dari Universitas Negeri Yogyakarta, 
